\title{
SCRAPIE: EFFECT OF Dh GENE ON INCUBATION PERIOD OF EXTRANEURALLY INJECTED AGENT
}

\author{
A. G. DICKINSON \\ and \\ H. FRASER \\ A.R.C. Animal Breeding Research Organisation, Edinburgh, EH9 310 \\ Moredun Research Institute, Edinburgh, EH17 7JH
}

Received 11.ii.72

\section{INTRODUCTION}

ONLY one gene has previously been found to have a major effect on the pathogenesis of scrapie in mice: the gene sinc controls the incubation period of all strains of scrapie agent which have so far been isolated in mice (Dickinson and Meikle, 1971). The two known alleles of sinc, $s 7$ and $p 7$, apparently act on some early phase of agent replication in each tissue (Dickinson and Fraser, 1969; Dickinson, Meikle and Fraser, 1969) and in consequence the effect of the gene on incubation period is seen following either intraneural or extraneural routes of injection (Dickinson and Meikle, 1969). With intraperitoneal injection the incubation period is longer than with intracerebral injection. In the latter case, replication of injected agent which persists in the brain evidently leads to the death of the recipient even though much of the inoculum passes to organs of the reticulo-endothelial system where replication can be shown to take place (Fraser and Dickinson, 1970; Hunter, Kimberlin and Millson, 1972): with intracerebral injection it is reasonable to infer that the two alleles of sinc determine variation in the incubation period entirely because of their effect within nervous tissues. However, following intraperitoneal injection the genetical control of the longer incubation period is almost certainly due to the composite effect of sinc in organs of the reticulo-endothelial system, such as the spleen, together with its subsequent effect in nervous tissue.

The gene $D h$ (dominant hemimelia) is almost always lethal in the homozygous combination, while in heterozygotes the spleen is absent and various degrees of hind limb abnormalities occur (Searle, 1964). The effect of this gene on scrapie incubation is confined to extraneural injections as will be seen from the results which are presented in this paper.

\section{MAterials AND METHODS}

The mouse stock used segregates for $D h$ and had been maintained as outbred matings by Dr A. G. Searle who supplied the nucleus stock which was then inbred by sib mating: mice for the experiment were from the 2nd to 4 th inbred generations. This stock is also carrying the $s 7$ allele of sinc (or an allele at present indistinguishable from $s 7$ ) because it has shorter incubation periods for intracerebrally injected ME7 scrapie agent than for the $22 \mathrm{~A}$ strain of agent.

Each mouse was injected either intracerebrally $(0.02 \mathrm{ml}$.) or intraperitoneally $(0.1 \mathrm{ml}$.) with the supernatant $(500 \mathrm{~g}$., 10 minutes) of a 1 per 
cent. saline homogenate of ME7-infected C57BL brain: this dose contains approximately $10^{4}{ }_{\text {L55 }}$ units, as estimated by intracerebral injection of C57BL mice. The age at injection ranged from 3 to 17 weeks: $D h /+$ and $+/+$ mice were evenly represented throughout this age range.

\section{Results AND DisGussion}

All the mice developed scrapie and each was checked when killed for the presence of a spleen as the criterion for the $D h /+$ genotype. Table 1 shows

TABLE 1

Incubation periods (days \pm S.E.) of ME7 scrapie in mice zeithout spleens $(\mathrm{Dh} /+)$ and in their normal litter mates $(+1+)$

\begin{tabular}{|c|c|c|c|}
\hline \multirow{2}{*}{$\begin{array}{l}\text { Route of } \\
\text { injection }\end{array}$} & \multicolumn{2}{|c|}{ Genotype } & \multirow[b]{2}{*}{$\mathrm{P}$} \\
\hline & $+1+$ & $\overrightarrow{\mathrm{Dh} /+}$ & \\
\hline $\begin{array}{l}\text { ntracerebral } \\
\text { ntraperitoneal }\end{array}$ & $\begin{array}{l}181 \pm 4 \\
226 \pm 2\end{array}$ & $\begin{array}{l}172 \pm 4 \\
282 \pm 11\end{array}$ & $\begin{aligned} & >0.2 \text { (Students " } t \text { ") } \\
< & <0.01 \text { (Fisher-Behrens " } t \text { ") }\end{aligned}$ \\
\hline
\end{tabular}

that there was no significant difference in incubation period due to the $D h$ gene following intracerebral injection of ME7 but the heterozygotes had a much longer average incubation when the intraperitoneal route was used. The spleenless mice injected intraperitoneally had much more variable incubation periods than the ones with spleens $(P>0.001)$. This indicates that there is much more variability in the relevant physiological or structural expression of the $D h$ allele than would be expected if the effect on scrapie were entirely dependent on the simple presence or absence of the spleen-variation in other components of the reticulo-endothelial system needs to be considered as a likely explanation. Although some spleenless mice were among the earliest cases in the intraperitoneal injection group the average increase in incubation period of 56 days is much longer than that reported for the effect of splenectomy in adult C57BL mice, given approximately the same dose as here of ME7 agent (Fraser and Dickinson, 1970), or in BSVS (Compton) mice with "Chandler" agent (Clarke and Haig, 1971).

These results provide further support for the importance of organs of the reticulo-endothelial system as sites of scrapie agent replication.

Experiments using extraneural routes of injection are obviously of more relevance than ones involving intraneural routes to questions of natural susceptibility to diseases such as scrapie. Rational attempts to modify the course of such natural infections are likely to depend on detailed understanding of the course of pathogenesis and, in this context, host control mechanisms, which can be detected as genetical variants, are important. With the daunting time-span involved in studies of " slow-virus" diseases it is tempting, because of the shorter times involved, to use only the intracerebral route, but this policy is probably shortsighted so far as control of the disease is concerned.

\section{Summary}

1. The incubation period of ME7 scrapie agent is 20 per cent. longer (56 days) in spleenless, $D h /+$, mice injected intraperitoneally than in their normal, $+/+$, litter mates. 
2. Following intracerebral injection, however, $D h /+$ and $+1+$ mice do not have significantly different incubation periods.

3. The results provide further evidence for the importance of the reticuloendothelial system as a site for scrapie agent replication.

Acknowledgment.-We thank Miss E. Whitfield for assistance with the experiments.

\section{REFERENCES}

CLARKE, M. C., AND HAIG, D. A. 1971. Multiplication of scrapie agent in mouse spleen. Res. Vet. Sci., 12, 195-197.

DICKINSON, A. G., AND FRASER, H. 1969. Genetical control of the concentration of ME7 scrapie agent in mouse spleen. F. comp. Path., 79, 363-366.

DICKINSON, A. G., AND MEIKLE, V. M. H. 1969. A comparison of some biological characteristics of the mouse-passaged scrapie agents, 22A and ME7. Genet. Res., Camb., 13, 213-225. DICKINSON, A. G., AND MEIKLE, v. M. H. 1971. Host-genotype and agent effects in scrapie incubation: change in allelic interaction with different strains of agent. Molec. gen. Genet., 112, 73-79.

DIGKINSON, A. G., MEIKLE, V. M. H., AND FRASER, H. 1969. Genetical control of the concentration of ME7 scrapie agent in the brain of mice. F. comp. Path., 79, 15-22.

TRASER, H., AND DICKINSON, A. G. 1970. Pathogenesis of scrapie in the mouse: the role of the spleen. Nature, 226, 462-463.

HUNTER, G. D., KIMBERLIN, R. H., AND MILLSON, G. C. 1972. Absence of eclipse phase in scrapie mice. Nature, New Biol., 235, 31-32.

SEARLE, A. G. 1964. The genetics and morphology of two "luxoid" mutants in the house mouse. Genet. Res., Camb., 5, 171-197. 